\title{
Estimate of thermal fatigue lifetime for the INCONEL 625ICF plate while exposed to concentrated solar radiation ${ }^{(\cdot)}$
}

\author{
A. Rojas-Morín* and J. Fernández-Reche**
}

\begin{abstract}
A system for testing the thermal cycling of materials and components has been developed and installed at the DISTAL-I parabolic dish facility located at the Plataforma Solar de Almería (PSA) in Spain. This system allows us to perform abrupt heating/cooling tests by exposing central solar receiver materials to concentrated solar radiation. These tests are performed to simulate both the normal and critical operational conditions of the central solar receiver. The thermal fatigue life for the INCONEL $625 \mathrm{LCF}^{\circledR}$ plate when subjected to concentrated solar radiation has been estimated with this system. We have also developed a numerical model that evaluates the thermal behavior of the plate material; additionally, the model yields the tensile-compressive stresses on the plate, which allow the estimation of the Stress-Life (S-N) fatigue curves. These curves show that the lifetime of the plate is within the High Cycle Fatigue (HCF) region at the operational temperatures of both $650{ }^{\circ} \mathrm{C}$ and $900{ }^{\circ} \mathrm{C}$
\end{abstract}

\section{Estimación del tiempo de vida bajo fatiga térmica para una placa de inconel $625 \mathrm{ICF}$, mientras se expone a radiación solar concentrada}

\begin{abstract}
Resumen
En el concentrador solar de disco parabólico DISTAL-I, situado en la Plataforma Solar de Almería (PSA), en España, se ha instalado un sistema para pruebas de ciclado térmico de materiales. Este sistema permite realizar pruebas abruptas de calentamiento y enfriamiento, en materiales para receptores solares de torre central, al exponerlos a radiación solar concentrada. Estas pruebas se realizan para simular las condiciones de operación de un receptor solar, las condiciones críticas y las condiciones normales. Con este sistema se ha estimado el tiempo de vida bajo fatiga térmica, en una placa de INCONEL $626 \mathrm{LCF}^{\circledR}$, cuando es sometida a radiación solar concentrada. Asimismo, hemos desarrollado un modelo numérico que evalúa el desarrollo térmico en el material de la placa: adicionalmente, el modelo obtiene los esfuerzos de tensión-compresión en la placa, los cuales permiten la estimaciónde las curvas de fatiga vidaesfuerzo (S-N). Estas curvas muestran que la vida útil de la placa se encuentra dentro de la región de Fatiga de Alto Ciclado (HCF) a temperaturas de operación de $650^{\circ} \mathrm{C}$ y $900^{\circ} \mathrm{C}$.
\end{abstract}

Palabras clave Pruebas de calentamiento; Pruebas de enfriamiento; Esfuerzos térmicos; Fatiga térmica; Placa de INCONEL.

\section{INTRODUCTION}

Due to the rising costs of fossil fuels (which are greenhouse gas emitters and contributors to global warming), technologies for generating electric power, such as solar towers, have become commercially important. Therefore, the importance of improving these technologies on a worldwide scale is increasing each day. In the very near future, these technologies will compete with conventional electric power generation technologies ${ }^{[1]}$. The solar tower plans consist of three major components: a heliostat field, a tower, and a central solar receiver that is towermounted. Of these components, the last one is critical to the operation ${ }^{[2]}$ because sunlight is concentrated onto the receiver, which absorbs it and transfers its energy to a heat-transfer fluid. Therefore, the materials used to produce solar receivers must be able to

\footnotetext{
(•) Trabajo recibido el día 22 de Junio de 2010 y aceptado en su forma final el día 14 de Diciembre de 2010.

* Centro de Ingeniería de Superficies y Acabados, Facultad de Ingeniería UNAM. Edif. Bernardo Quintana. $2^{\circ}$ Piso. Circuito Exterior. Ciudad Universitaria. C.P. 04510, D.F. México. Phone: +52 55562230 07. Fax: +52 55562230 07. e-mail: rm.armando@gmail.com.

** PSA-CIEMAT. Solar Concentrating Systems. P.O Box 22. E-04200 Tabernas-Almería SPAIN. Phone: +34 950387903 . Fax: +34 950 387969. e-mail: jesus.fernandez@psa.es.
} 
withstand severe operational conditions caused by high radiative fluxes generated by the heliostats. For the SOLAR TRES project ${ }^{[3]}$, which intends to raise the maximum solar flux at the receiver surface from $0.83 \mathrm{MW} / \mathrm{m}^{2}$ (SOLAR TWO value) to 1.2 $\mathrm{MW} / \mathrm{m}^{2}$, this increase in radiative flux requires an innovative receiver design as well as materials that are capable of withstanding high thermal stresses. The thermal stresses generated on the surface of these materials are significantly increased; they are caused by heating and cooling processes that consist of daily switching on and switching off and variations in atmospheric conditions, such as partial or total cloudiness. Thus, the operational lifetime of a costcompetitive central tower facility must be at least 30 years, which will permit a minimum of 10,000 to 15,000 thermal cycles on the solar receiver. Due to this requirement, materials used to produce solar receivers must withstand stresses caused by thermal fatigue throughout the lifetime of the receiver.

Useful lifetime predictions have been generated for materials that undergo thermal fatigue, but these predictions have been made for conventional industrial applications, such as heat exchangers ${ }^{[4]}$, steam generators ${ }^{[5}$ and 6$]$, and conventional furnaces ${ }^{[7}$ and 8$]$.

None of these predictions have estimated the durability of solar receiver materials.
Therefore, the present work seeks to estimate the lifetime of an INCONEL $625 \mathrm{LCF}^{\circledR}$ plate that is subjected to thermal cycling by using concentrated solar radiation that is produced by the DISTAL I parabolic dish.

The manuscript is organized as follows: Section 2 describes the testing facility at the Plataforma Solar de Almería (PSA), a ray-tracing analysis that models the facility, a numerical simulation that determines the temperature distribution on the plate, and the experimental cycling test for the plate; section 3 shows the experimental temperature evolution, a comparison of these results against numerical simulations, the thermal stress calculation, and the Stress-Life curve (S-N) estimate of the plate lifetime; finally, Section 4 discusses the main conclusions of the manuscript.

\section{MATERIALS AND METHODS}

\subsection{Facility description}

The DISTALI ${ }^{[9]}$ is a prototypical parabolic dish that has been installed at the PSA since 1992 (Fig. 1). The concentrator consists on a 7.5-m diameter parabolic

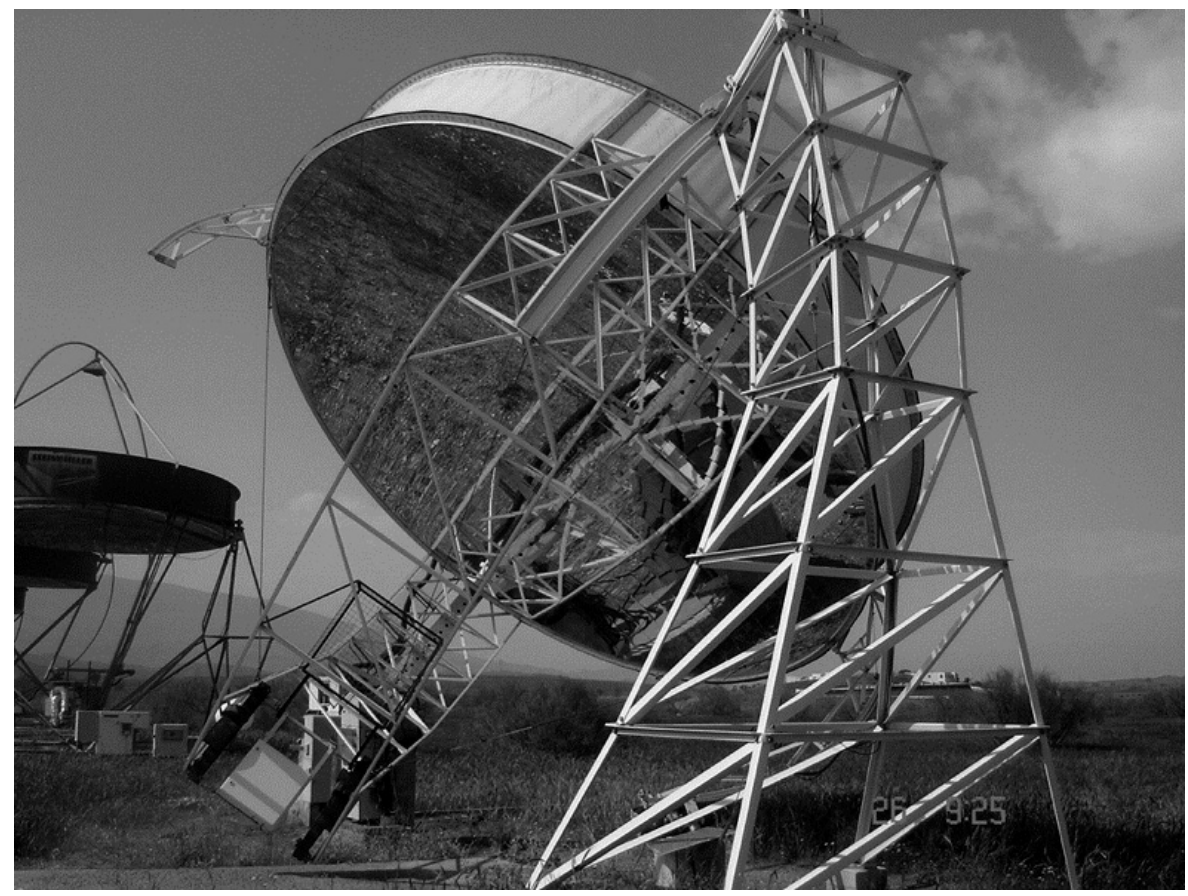

Figure 1. DISTAL I parabolic dish at the Plataforma Solar de Almería, Spain.

Figura 1. Disco parabolico, DISTAL I, en la Plataforma Solar de Almería, España. 
mirror. The mirror is glued to a tensioned membrane in order to maintain the parabolic shape. Controlling the vacuum near the rear surface of the membrane allows the reshaping of the parabolic surface. Formerly, the concentrator was associated with a helium tube receiver coupled with a SOLO ${ }^{\circledR}$ Stirling engine, which generated $9 \mathrm{~kW}$ of electric power. All of the devices are mounted on a polar mount that follows the sun throughout the day. The elevation is fixed every day at startup, and the equatorial axis moves the entire system $15^{\circ}$ per hour. Table I summarizes the main parameters of the DISTAL-I dish.

To perform the accelerated aging test, the receiver and the engine have been replaced by a positioning device where the receiver materials are installed. A pneumatic arm (Fig. 2) moves the testing frame in the tangential direction. A metallic jail is used to prevent parts of the device from falling down to the dish mirror. A Direct Current (DC) motor also allows the frame to move in a radial direction so

Table I. Summarizes the main parameters DISTAL I dish

Table I. Características principales del disco parabolico DISTAL I

\begin{tabular}{lc}
\hline Mirror diameter & $7.5 \mathrm{~m}$ \\
Focal distance & $4.5 \mathrm{~m}$ \\
Mirror reflectance & 0.94 \\
Focus diameter & $0.12 \mathrm{~m}$ \\
Thermal power & $40 \mathrm{~kW}$ \\
\hline
\end{tabular}
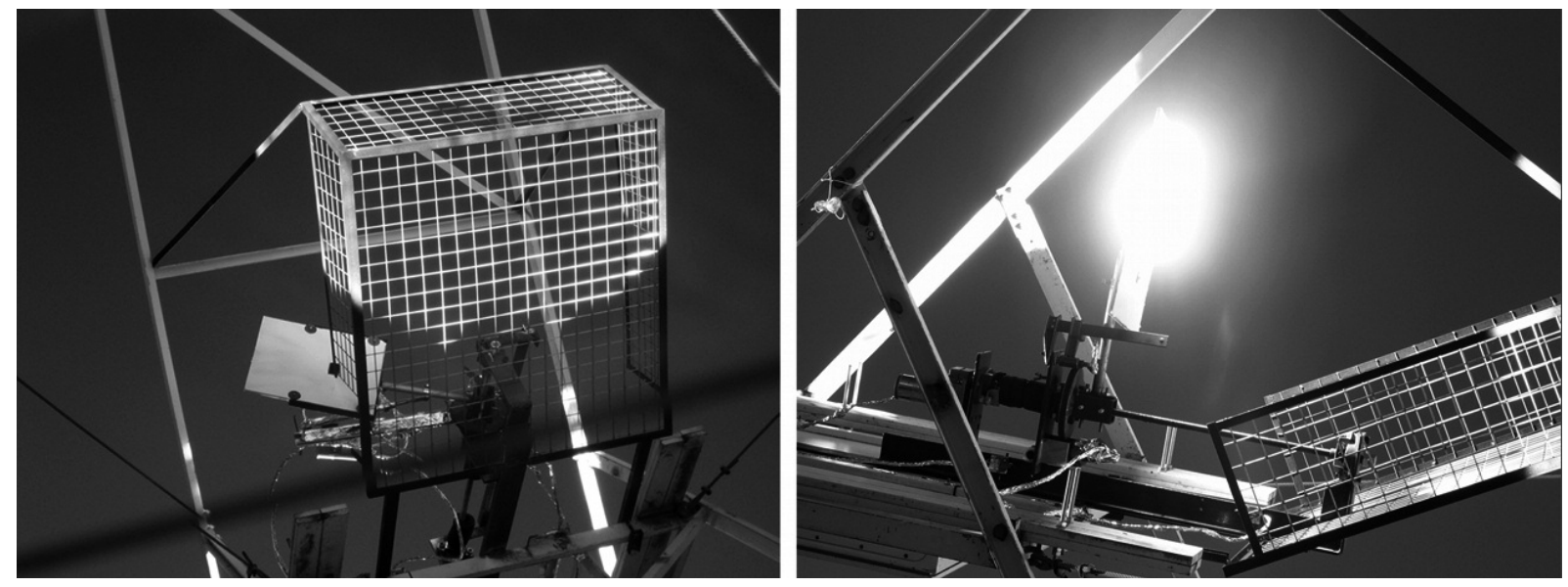

Figure 2. Experimental device for thermal cycling of solar receiver material installed on the DISTAL I at the PSA (right image: receiving direct sun light; left image: not receiving direct sun light).

Figura 2. Sistema experimental para ciclado térmico de materiales para receptores solares, instalado en el DISTAL I en la PSA, (figura a la izquierda: la muestra no recibe directamente la luz solar, figura a la derecha: la muestra recibe directamente la luz solar). that the materials can be positioned at various locations along the radial focal distance. During this process, the pneumatic arm thermally cycles the materials by moving them in and out of the dish focus, and the DC motor irradiates the materials at various flux levels on the front side.

To accelerate the cooling of the materials and to increase the number of cycles performed daily, the system is designed so that a pressurized air pipe is joined to a blower that blows air to the back side of the pieces when the frame is outside of the focus. This device configuration allows the installation of thermocouples on the rear surface of the test specimens as well as load cells to monitor both the temperature distribution on the materials and the tension supported by the materials during the heating/cooling processes. An aluminum oxide plate has been installed to prevent any damage to the system due to solar radiation (Fig. 3).

To monitor and control the entire system, a System Control and Data Acquisition (SCADA) system has been developed using IMP I/O acquisition modules (Solartron/Mobrey ${ }^{\circledR}$ ) and LabVIEW ${ }^{\circledR}$ software (National Instruments), which monitors all of the input/output variables during testing and controls the thermal cycles automatically by checking the maximum temperatures reached by the materials.

\subsection{Ray-tracing analysis}

Several ray-tracing analyses of solar concentrators have been performed ${ }^{[10]}$ to examine the parabolic dish flux distribution and optically characterize 


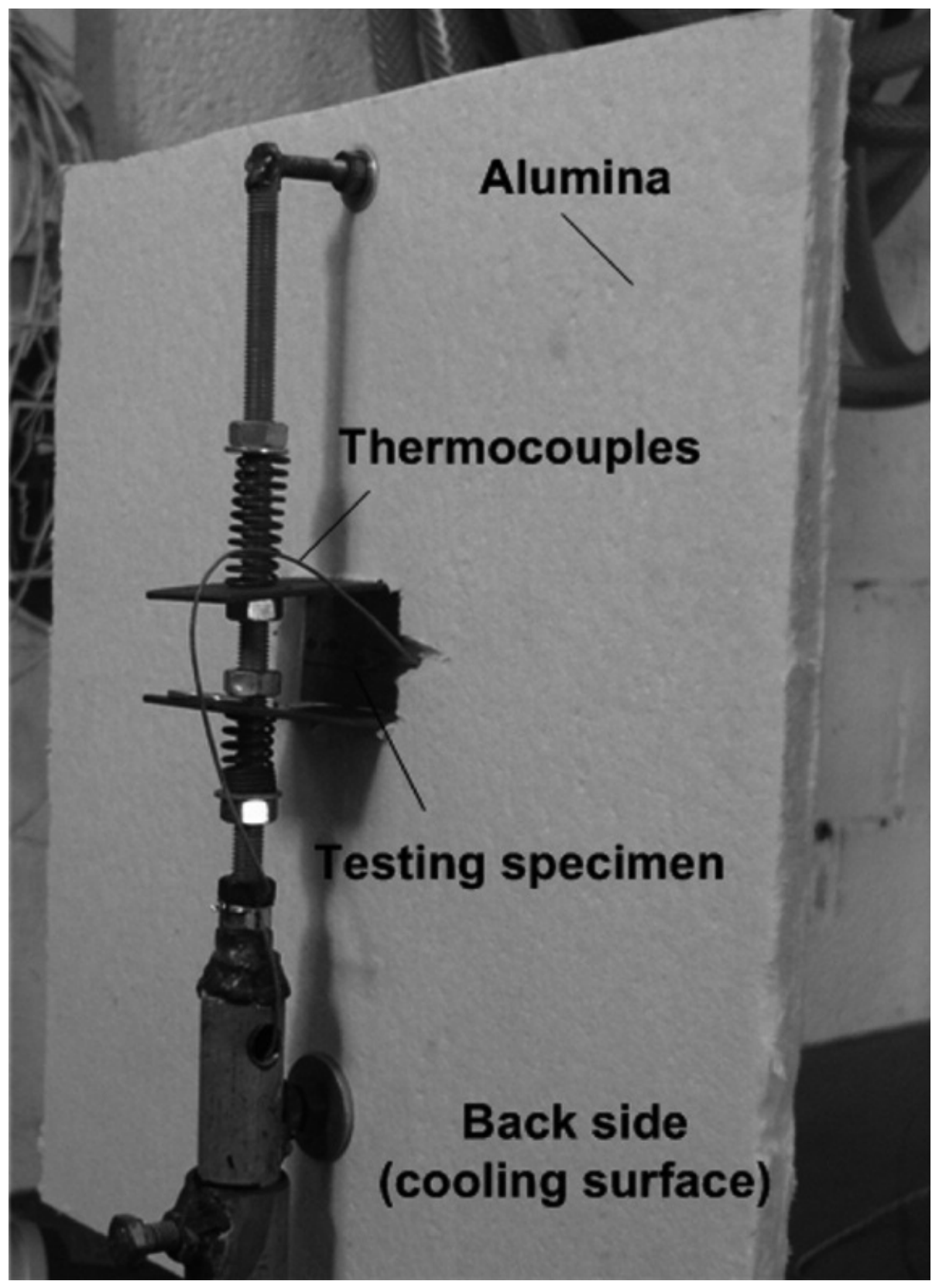

Figure 3. Experimental test settings.

Figura 3. Descripción del sistema experimental.

such systems. For the case of DISTAL I, a ray-tracing analysis was performed to determine the flux of Direct Normal Irradiance (DNI) levels at various radial positions. This analysis was performed using the SolTRACE code developed by the National Renewable Energy Laboratory (NREL) ${ }^{[11]}$. This code allows the analysis of more complex systems than those analyzed using Optical Model of Solar Dish Concentrators (OPTDSH) codes $^{[12]}$ or Convolution of Incident Radiation with Concentrator Errors (CIRCE) codes ${ }^{[13]}$. The raytracing simulations of the DISTAL I were performed at various positions of the target (Stage 1: element 2), taking as reference the focal plane of the parabolic dish (Stage 1: element 1 ) at $4.50 \mathrm{~m}$ and varying this position $+0.05 \mathrm{~m}$ outward and $-0.05 \mathrm{~m}$ inward along the $Z$ axis (Fig. 4). The white zone in the parabolic dish represents missing rays from the concentrator due to the target position.

Results of ray-tracing analysis for the target positioned at $4.65 \mathrm{~m}$ and $4.70 \mathrm{~m}$ are presented in figures 5 and 6 , respectively. The solar flux peaks were determined at approximately $900 \mathrm{~kW} / \mathrm{m}^{2}$ and $500 \mathrm{~kW} / \mathrm{m}^{2}$, respectively. Appropriate plate positions 


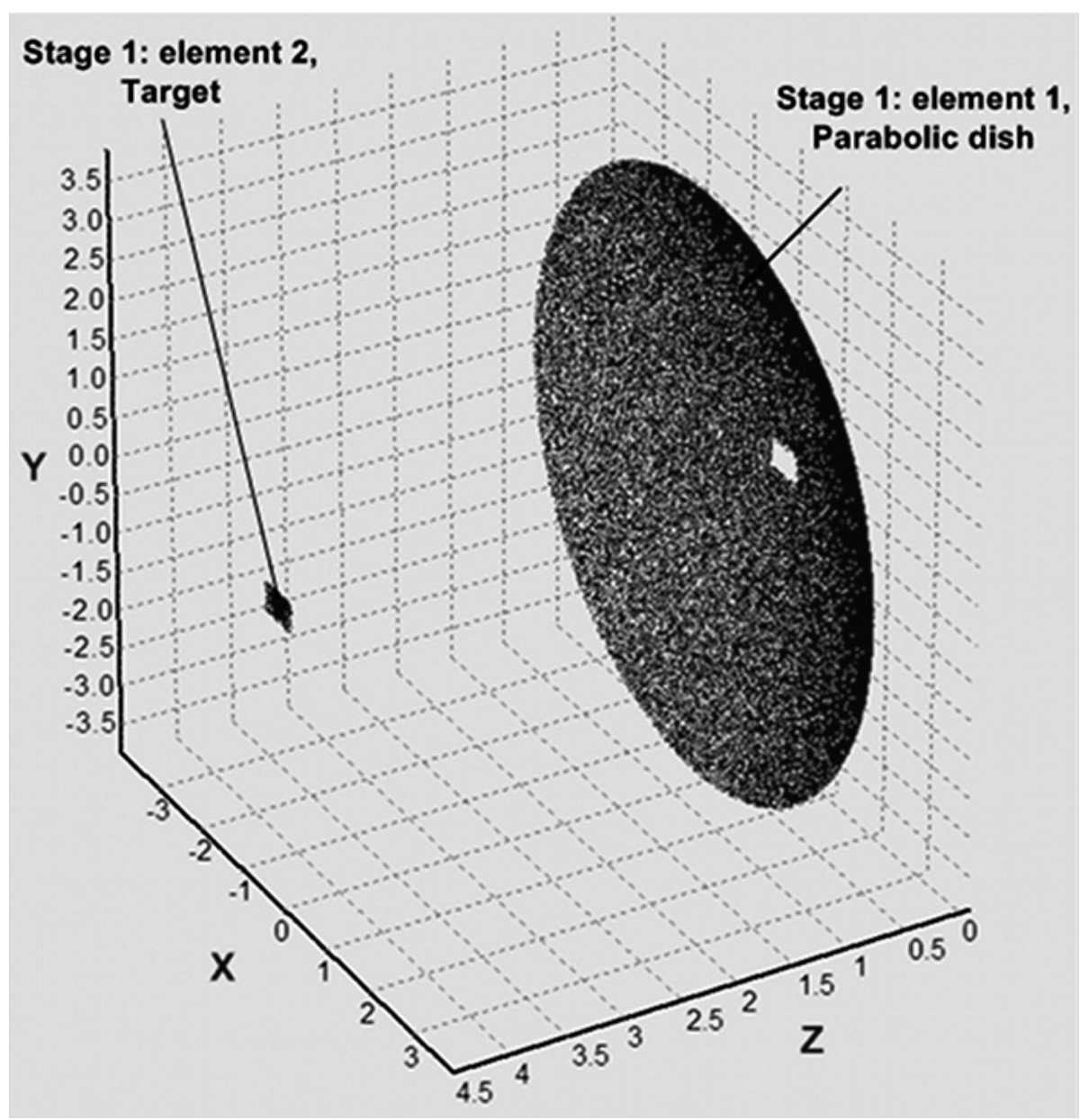

Figure 4. Ray-tracing analysis for the DISTAL I at a target position at $4.50 \mathrm{~m}$ (absolute coordinate system).

Figura 4. Análisis de trazado de rayos para el DISTAL I, a una posición del objetivo de 4,5 m (sistema coordenado absoluto).

for the experimental thermal cycling tests were determined based on this analysis.

\subsection{Simulation analysis}

\subsubsection{Formulation}

Before starting the testing, a simulation program ${ }^{[14 \text { and } 15]}$ was developed that considered a sample of the INCONEL $625 \mathrm{LCF}^{\circledR}$ sheet that had the same dimensions as the plate. In this case, the simulation obtained the temperature distribution and its evolution over time for the heating and cooling processes. The following assumptions have been made: the plate is fixed in a Cartesian coordinate system with three-dimensional conduction $(x, y, z)$, the temperature evolution is for the transient state, solar radiation flux occurs only on the front plane, and convective heat losses occur only on the back plane. Figure 7 shows the energy balance on the plate, where q" rad is the incident solar radiation flux on the surface, $q^{\prime \prime}$ conv represents the convective heat losses, and $q^{\prime \prime}$ cond is the conductive heat from the surface temperature distribution.

The heat conduction equation becomes:

$$
\frac{\partial^{2} T}{\partial x^{2}}+\frac{\partial^{2} T}{\partial y^{2}}+\frac{\partial^{2} T}{\partial z^{2}}=\frac{1}{\alpha} \frac{\partial T}{\partial t}
$$

where $\alpha$ is the thermal diffusivity:

$$
\alpha=\frac{k}{\rho C_{p}}
$$

where $k$ is the thermal conductivity $\rho$ is the density, and $\mathrm{C}_{p}$ is the specific heat capacity. 

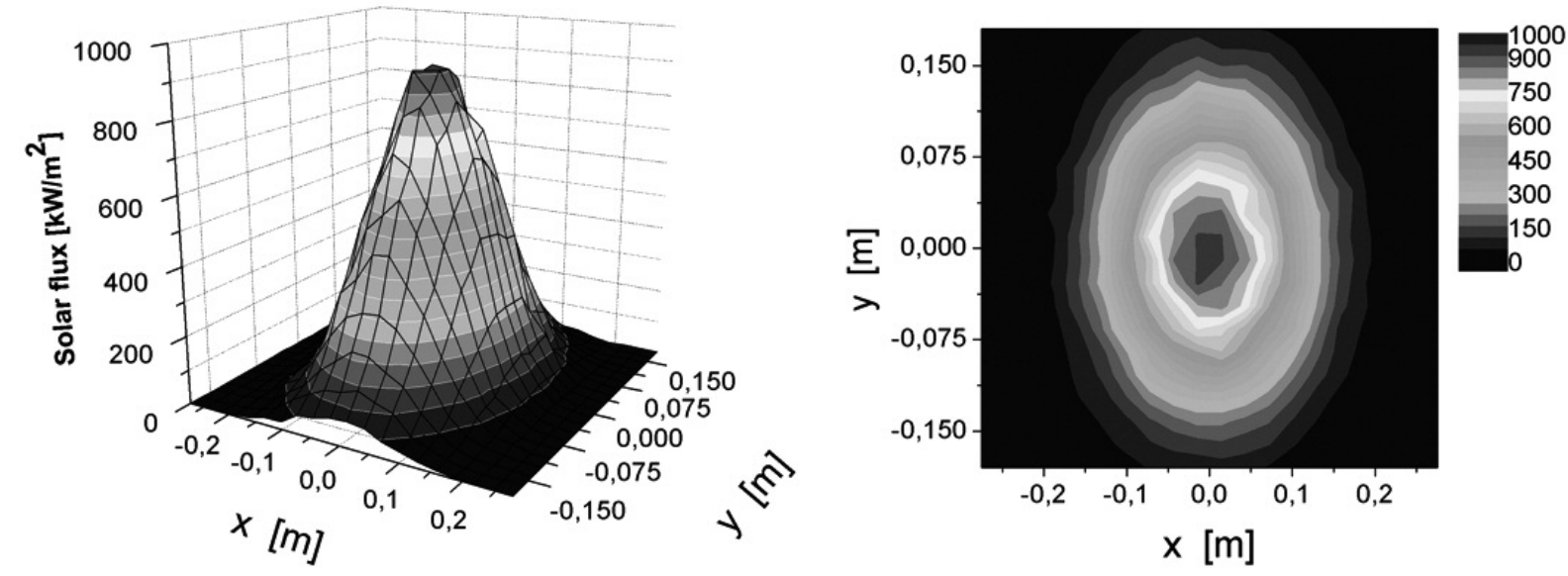

Figure 5. Solar flux distribution at the target at a position of $4.65 \mathrm{~m}$ on the focal axis.

Figure 5. Distribución de flujo solar sobre el objetivo, distancia focal de 4,65 m.
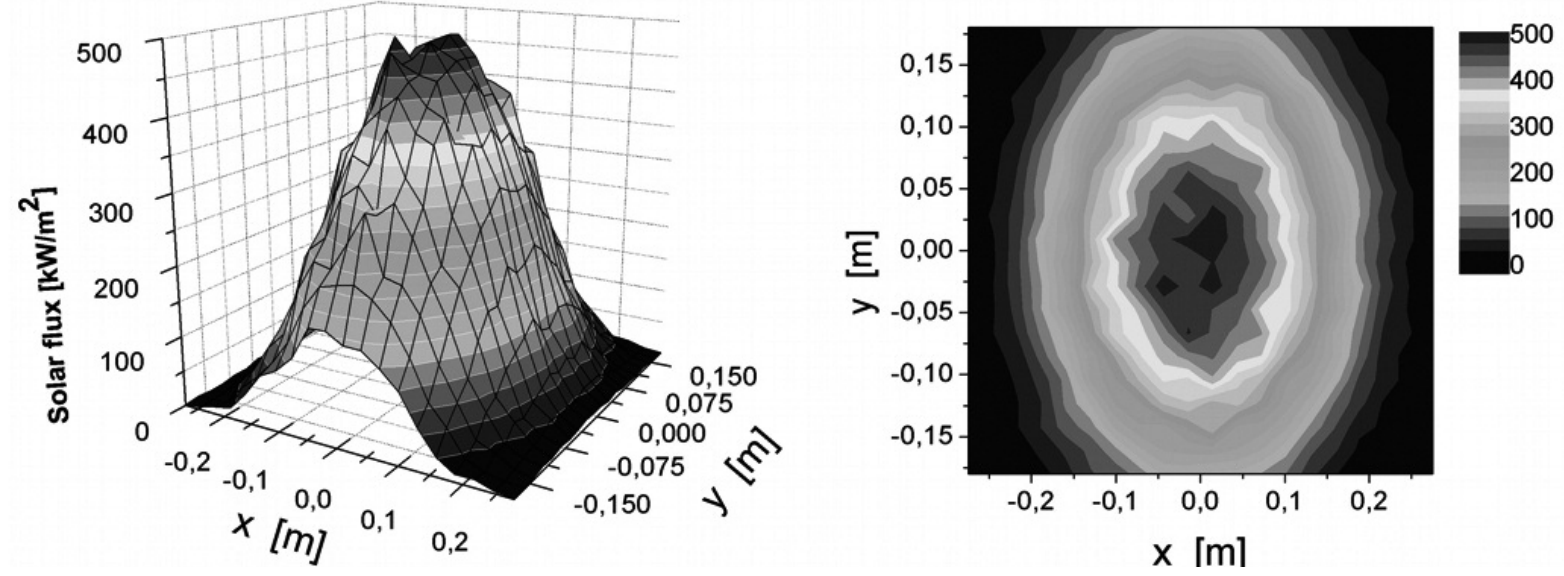

Figure 6. Solar flux distribution at the target at a position of $4.70 \mathrm{~m}$ on the focal axis.

Figure 6. Distribución de flujo solar sobre el objetivo, distancia focal de 4,70 m.

Equation (1) is subject to the following boundary and initial conditions:

Radiation surface:

$$
\text { at } z=0: q^{\prime \prime}{ }_{r a d}=-k \frac{\partial T_{(x, y, 0, t)}}{\partial z}=\varepsilon \sigma\left(T^{4}-T_{\infty}^{4}\right) \text { if } t \geq t_{c}
$$

Convection surface:

$$
\text { at } z=t_{k}:-k \frac{\partial T}{\partial z}=h\left[T_{\infty}-T_{(x, y, z, t)}\right]
$$

Initial condition:

$$
\text { at } t=0: T_{(x, y, z, t=0)}=T_{\infty}
$$

where $\varepsilon$ is the emissivity of the surface, $\sigma$ is the Stefan-Boltzmann constant, $T_{\infty}$ is the fluid temperature far from the surface and $t_{c}$ is the initial time for cooling. The heat flux $q^{\prime \prime}$ rad was obtained from the ray-tracing analysis (section 2.2) and $h$ is the average convective heat transfer coefficient that is found by the following equation:

$$
\bar{h}=\frac{N u_{L} k}{L}
$$

where $N u_{L}$ is the Nusselt number and $L$ is the total length on the $y$ axis of the plate. The Nusselt number 


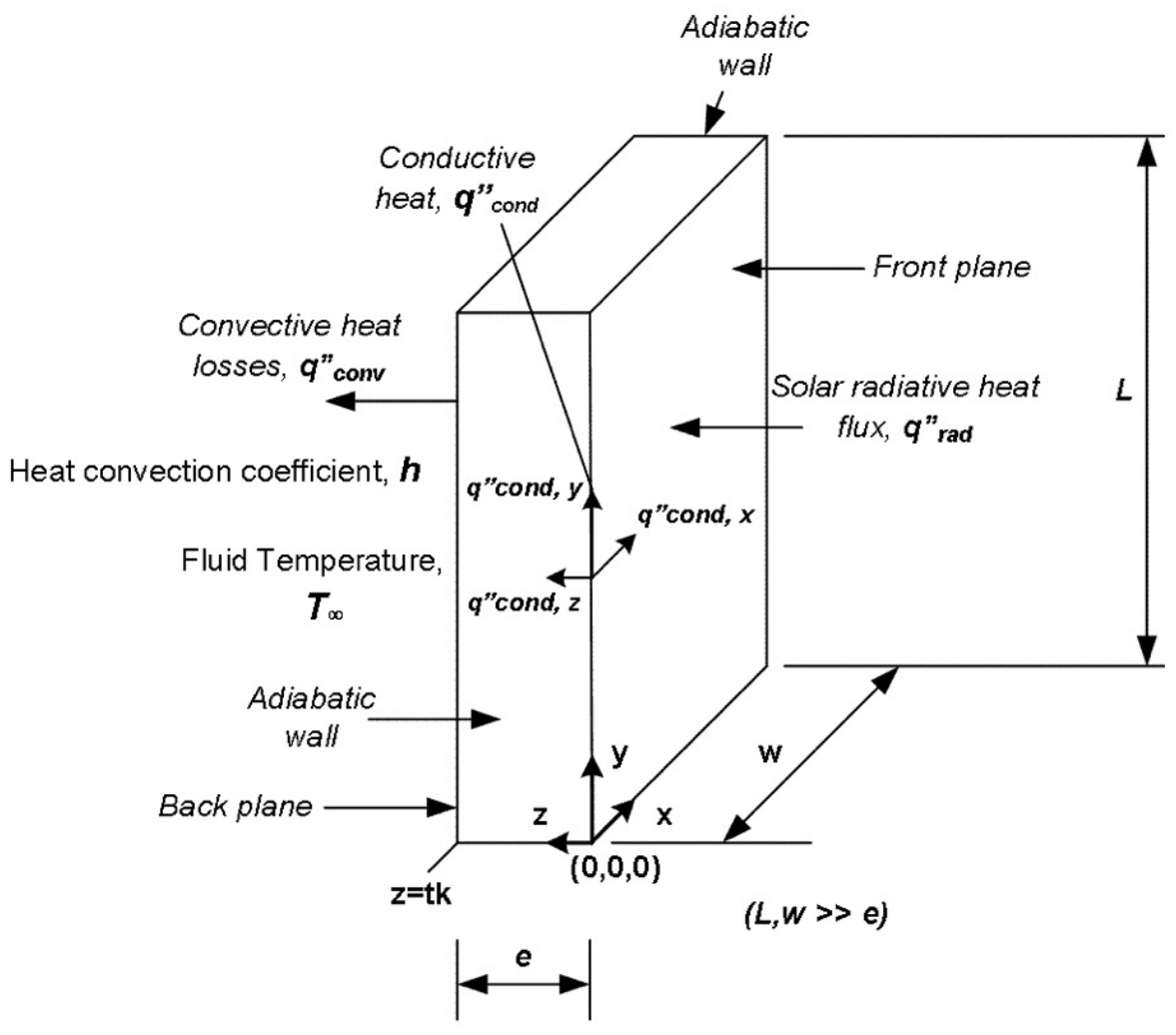

Figure 7. Energy balance on the plate.

Figure 7. Balance de energía en la placa.

is determined by the following empirical correlation $^{[16]}$ :

$$
N u_{L}=0.332 \operatorname{Re}_{L}^{(1 / 2)} \operatorname{Pr}^{(1 / 3)}
$$

where $R e_{L}$ is the Reynolds number and $\operatorname{Pr}$ is the Prandtl number for the fluid temperature far from the surface.

\subsubsection{Finite difference method}

Since the boundary conditions for the radiation and convection surfaces were not of the first class type, the surfaces temperature distribution was not known, and therefore, it was not possible to make a direct interpolation between the surfaces to obtain the temperatures in the conduction plane. Moreover, the radiation boundary condition is nonlinear (equation 3); therefore, it was necessary to carry out a numerical procedure to solve equation 1 for which the finite difference method has been used. As a first attempt, and for the reason just specified, a reduced number of 45 nodal equations was developed and solved by the matrix inverse method, via a Matlab ${ }^{\circledR}$ program. The nodal equations were represented by the following matrix equation:

$$
\left[T_{(m, n, p)}\right]^{(t+1)}=\left[A_{(m, n, p)}^{-1}\right]^{(t+1)} \cdot\left[C_{(m, n, p)}\right]^{(t)}
$$

where $T_{(m, n, p)}$ is the nodal temperature at time $(t+1)$, $\mathrm{A}_{(m, n, p)}$ is the coefficient matrix at time $(\mathrm{t}+1)$, and $\mathrm{C}_{(m, n, p)}$ gives the initial conditions of the matrix.

Subsequently, after obtaining the numerical solution for the temperatures of 45 nodes, an interpolation was performed on the three planes considered, which determined a significant temperature range of 15048 nodes. Using these data, figures 10 (right), 11, and 12, were obtained.

\subsection{Experimental cycling test}

The testing was performed on a $0.03 \times 0.04 \times$ $0.001 \mathrm{~m}^{3}$ Inconel $625 \mathrm{LCF}^{\circledR}$ plate painted with pyromark $-2500^{\circledR}$ high temperature coating. For this 
test, the temperature increased to $650^{\circ} \mathrm{C}$ and $900^{\circ} \mathrm{C}$ for normal and critical operational conditions, respectively.

Two thermocouples were placed at the convection plate (rear surface) to monitor the temperature evolution at this plane. The first thermocouple was placed at the $(3,1,3)$ node, and the second one was placed between nodes $(3,1,3)$ and $(2,5,3)$.

\section{RESULTS AND DISCUSSION}

\subsection{Temperature evolution}

Figure 8 shows the cycles performed on the plate in a $4.6 \mathrm{~h}$ operating day for the temperature evolution of experimental node $(3,1,3)$. Figure 9 shows the temperature evolution for the second thermocouple, TT1. More than 500 cycles were performed on the plate at a rate of $120 \mathrm{cycles} / \mathrm{h}$.

\subsection{Comparison with simulation}

The simulation results show the temperature increment of the plate for three planes: radiation, conduction, and convection during an entire heating/cooling cycle. Figure 10 (left) shows the temperature evolution for the following radiation plane nodes: $T(1,1,1), T(3,1,1), T(3,2,1), T(3,3,1)$, and $T(2,5,1)$. Due to the plate symmetry, the temperature at the other nodes is similar. Thus, at time $14 \mathrm{~s}$, the maximum temperature is approximately

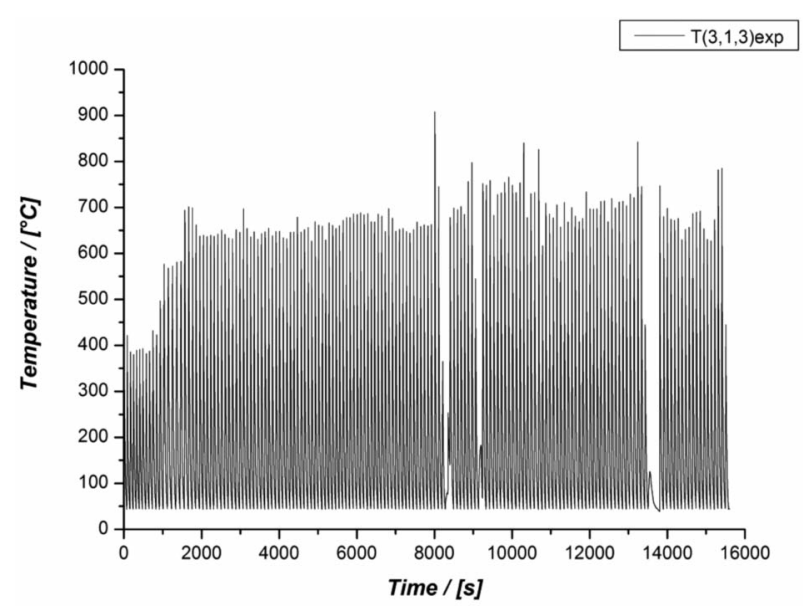

Figure 8. Plot of temperature during thermal cycling for node $(3,1,3)$ exp.

Figura 8. Evolución de la temperatura en el nodo $(3,1,3)$ exp durante la prueba de ciclado térmico.

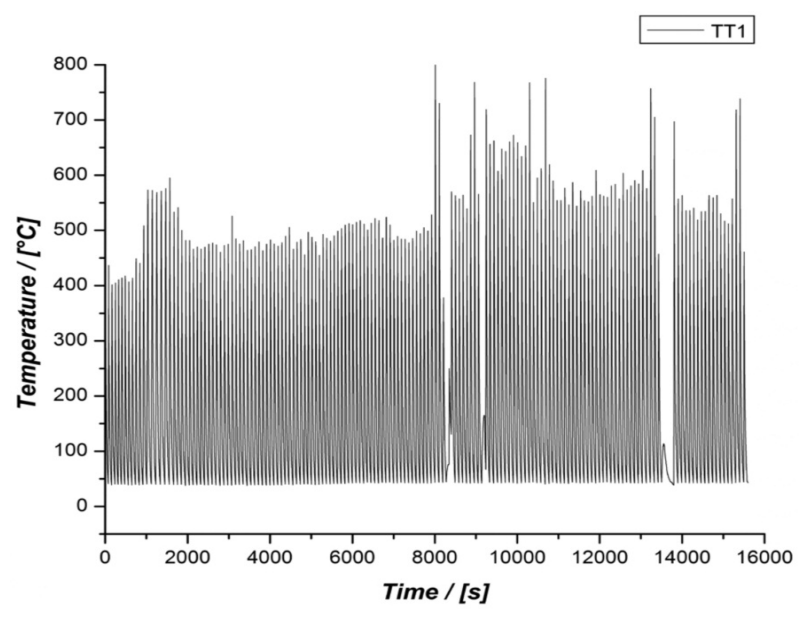

Figure 9. Plot of temperature during thermal cycling for the TT1 thermocouple.

Figure 9. Evolución de la temperatura experimental registrada por el termopar TT1, durante la prueba de ciclo térmico.

$1033^{\circ} \mathrm{C}$, which corresponds to that at the $T(3,3,1)$ node. Figure 10 (right) shows the numerical interpolation temperature distribution for this plane in units of ${ }^{\circ} \mathrm{C}$.

Figures 11 and 12 show the temperature evolution at the same nodes as shown in Figure 10, but at the conduction and convection planes, respectively. The maximum temperature is approximately 1025 ${ }^{\circ} \mathrm{C}$ at node $\mathrm{T}(3,3,2)$ (Fig. 11, left), and the maximum temperature at node $T(3,3,3)$ is approximately $1022^{\circ} \mathrm{C}$ (Fig. 12, left).

Figure 12 (left) also shows the results of a simulation comparison between the experimental temperature at $T(3,1,3) \exp$ and the numerical temperature at $T(3,1,3)$ num for an entire heating/cooling cycle at the convection plane. The maximum temperature at this node is approximately $700{ }^{\circ} \mathrm{C}$. The results show very good agreement between the values obtained from the model and those obtained from the experimental test. The experimental temperature, TT1exp, occurs between the $T(3,1,3)$ num and $T(2,5,3)$ num nodes. These simulation results (presented in Fig. 12) validate the model for the temperature distribution at the radiation, conduction, and convection planes.

\subsection{Thermal stress calculations}

Once again, the model is validated according to agreement between the experimental tests and the temperature distribution obtained from the 

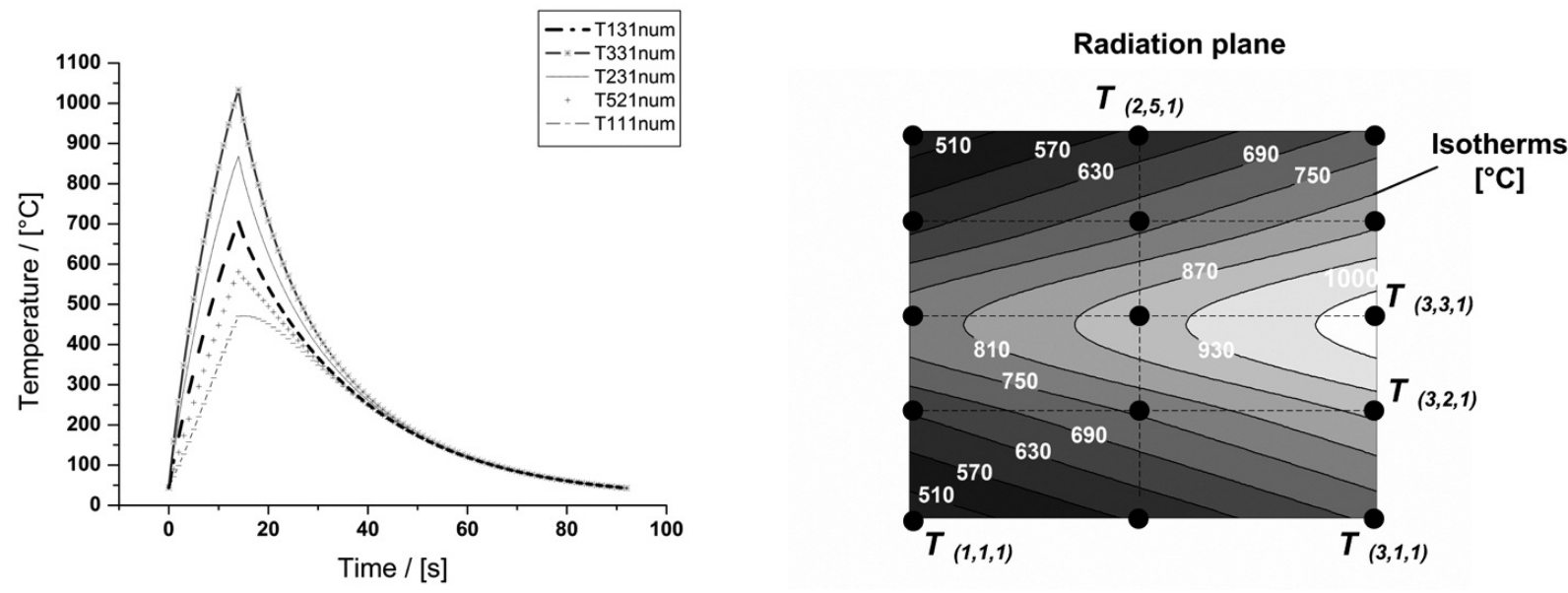

Figure 10. Left: simulation of temperature at the radiation plane during an entire heating/cooling cycle. Right: temperature distribution $\left({ }^{\circ} \mathrm{C}\right)$ of 15 nodes at the radiation plane.

Figura 10. Izquierda: simulación de la evolución de la temperatura en el plano de radiación, durante un ciclo de calentamiento y enfriamiento. Derecha: distribución de temperaturas $\left({ }^{\circ} \mathrm{C}\right)$ en el plano de radiación.
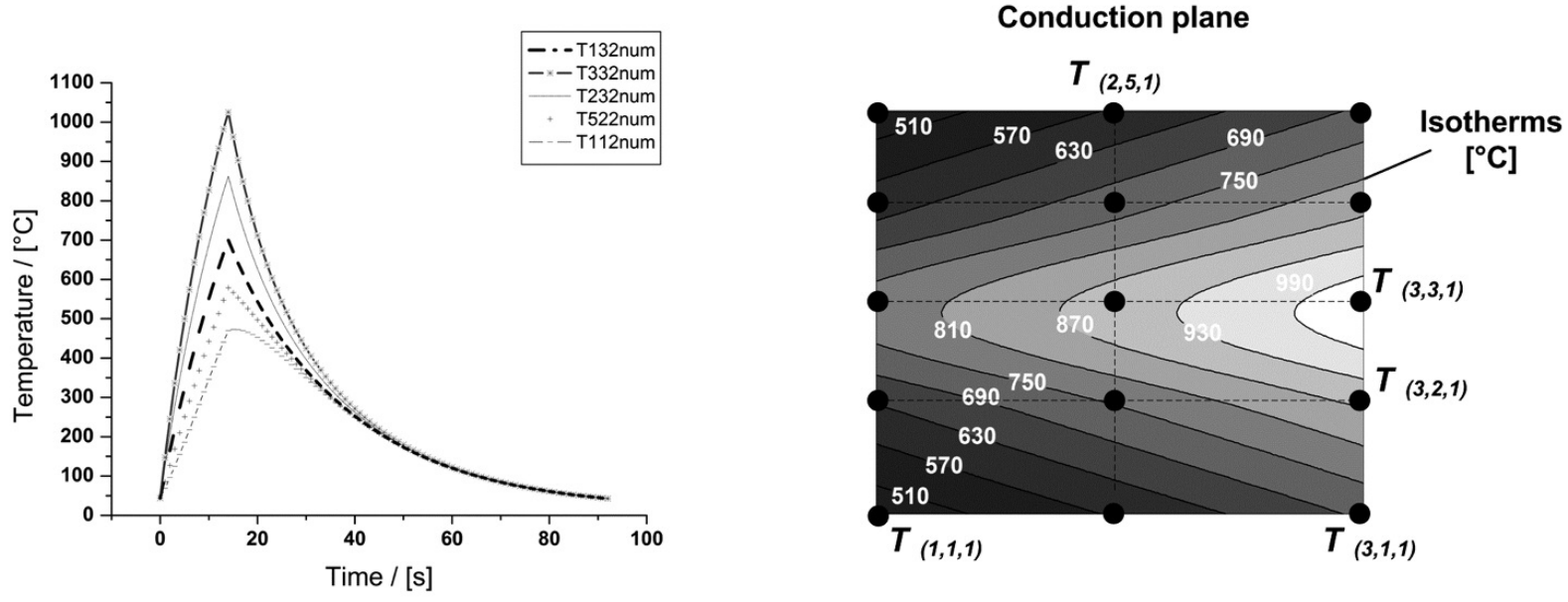

Figure 11. Left: simulation of temperature at the conduction plane during an entire heating/cooling cycle. Right: temperature distribution $\left({ }^{\circ} \mathrm{C}\right)$ of 15 nodes at the condution plane

Figura 11. Izquierda: simulación de la evolución de la temperatura en el plano de conducción, durante un ciclo de calentamiento y calentamiento y enfriamiento. Derecha: distribución de temperaturas $\left({ }^{\circ} \mathrm{C}\right)$ en el plano de conducción.

simulation. It is possible to evaluate the thermal tensile and compressive stresses $\left(\sigma_{t}\right)$ present in the heating and cooling processes, respectively, by using the following formula:

$$
\sigma_{t}=E \alpha\left(T_{i}-T_{i-1}\right)
$$

where $E$ is the metal elastic modulus, and $\alpha$ is the thermal expansion coefficient. $T_{i}$ and $T_{i-1}$ are the temperatures at times $t$ and $t-1$, respectively.
The empirical correlations and the tensile strength of the INCONEL $625 \mathrm{LCF}^{\circledR}$ (Table II) ${ }^{[17]}$ have been obtained from the elastic modulus and thermal expansion data for the temperature range of $20-1000^{\circ} \mathrm{C}$.

These tensions have been used to estimate the structural fatigue of the materials while they are irradiated by solar radiation. Figure 13 shows the thermal stress (calculated from equation 9) caused by the heating/cooling cycle and the experimental 


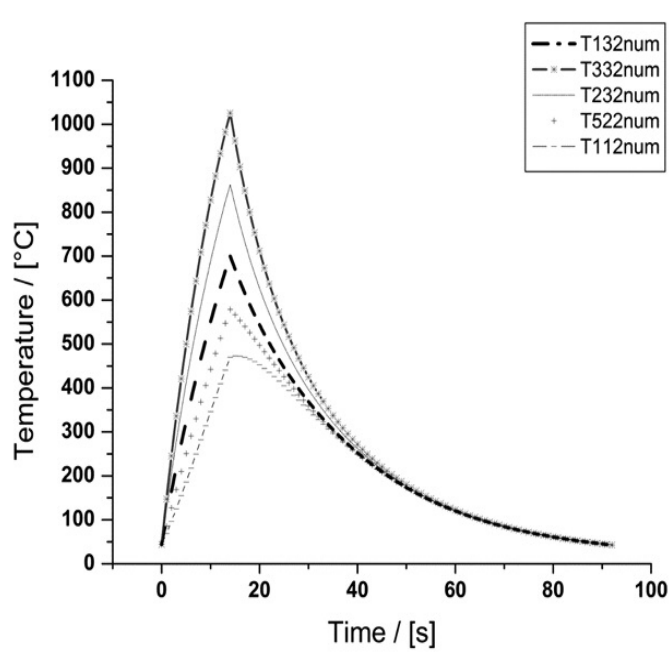

Left

\section{Convection plane}

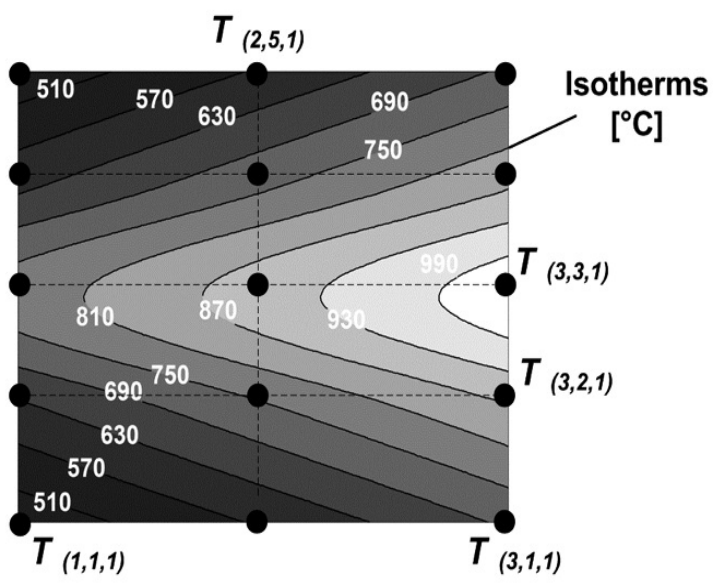

Right

Figure 12. Left: comparison between the measured and simulated temperature at the convection plane for node $(3,1,3)$ during an entire heating/cooling cycle. Right: temperature distribution $\left({ }^{\circ} \mathrm{C}\right)$ of 15 nodes at the convection plane.

Figura 12. Izquierda: Evolución de la temperatura en el plano de convección, nodo $(3,1,3)$ y su comparación entre la temperatura simulada y experimental, durante un ciclo de calentamiento y enfriamineto. Derecha: distribución de temperaturas $\left({ }^{\circ} \mathrm{C}\right)$ en el plano de convección.

Table II. Correlations and tensile strength for INCONEL 625LCF at annealing temperature $\left(955^{\circ} \mathrm{C}\right)$

Tabla II. Resistencia de tensión y correlaciones para el INCONEL 625LCF a temperatura de tratamiento térmico $\left(955^{\circ} \mathrm{C}\right)$

\begin{tabular}{ccc}
\hline$S_{u}[\mathrm{MPa}]$ & 894 & \\
$E[\mathrm{MPa}]$ & $\mathrm{E}=-59.954 T+209759$ & $R^{2}=0.9951$ \\
$\alpha \times 10^{-6}\left[{ }^{\circ} \mathrm{C}^{-1}\right]$ & $\alpha=3 \times 10^{-6} T^{2}+0.0014 T+12.671$ & $R^{2}=0.9944$ \\
\hline
\end{tabular}

temperature at node $(3,1,3)$ at the convection plane. For this case, the tensile stress is positive from 75 to $225 \mathrm{MPa}$ and sometimes rises to $300-400 \mathrm{MPa}$. The compressive stress is negative from $-60-150 \mathrm{MPa}$ and decreases to $-250 \mathrm{MPa}$. This stress difference produces a thermal fatigue on the INCONEL $625 \mathrm{LCF}^{\circledR}$ plate. For the estimated S-N fatigue curves, we selected significant stress values and classified them according to two different conditions: a Normal Operational Condition (OC) and a Critical Condition (CC). Figure 13 shows five selected points for the $\mathrm{OC}$ and six selected points for the CC, denoted by the upper $\left(S_{\max }\right.$ zone $)$ and lower $\left(S_{\min }\right.$ zone $)$ black arrows.

\subsection{S-N fatigue curve estimation}

Using the thermal stress values obtained during the cycling tests and simulation, we estimated the S-N fatigue curves for the INCONEL $625 \mathrm{LCF}^{\circledR}$ plate. The estimate was performed for two different temperature conditions of the solar receiver materials: normal and critical operational conditions. The normal temperature condition is the one for which the temperature of the solar receiver material rises at the stationary state.

The critical operational condition refers to the temperature due to focusing the heliostats on the solar receiver.

The estimate was performed by approximating the material fatigue curve $\mathrm{e}^{[18]}$. For this case, the S-N fatigue curves have two distinct slopes: the first slope is from $1-10^{3}$ cycles (Low Cycle Fatigue $(\mathrm{LCF})$ ), and the second slope is from $10^{3}-10^{11}$ cycles (High Cycle Fatigue (HCF)). The fatigue curve of the material was evaluated according to the stress range by using the Basquin equation ${ }^{[19]}$ :

$$
S_{N_{f}}=A\left(N_{f}\right)^{B}
$$

where $S_{N F}$ is the stress that results in a fatigue failure for any stress range $S_{r}, N_{f}$ is the number of cycles 


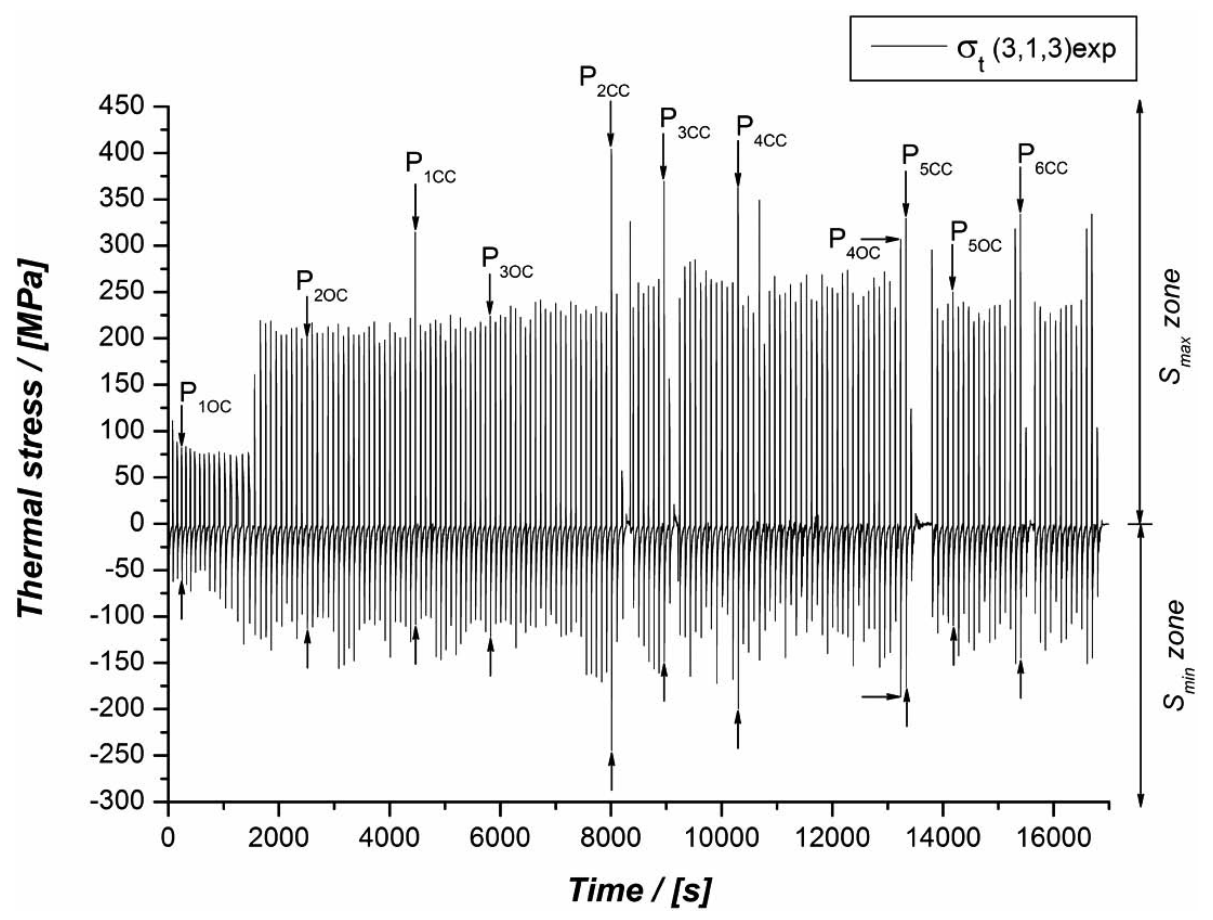

Figure 13. Thermal stresses supported by the INCONEL 625LCF plate during the heating and cooling processes. The points selected for normal operational condition (OC) are $\mathrm{P}_{10 \mathrm{C}}, \mathrm{P}_{20 \mathrm{C}}, \mathrm{P}_{30 \mathrm{C}}, \mathrm{P}_{40 \mathrm{OC}}$, and $P_{50 C}$. The points selected for critical conditions (CC) are $P_{1 C C}, P_{2 C C}$, $\mathrm{P}_{3 C C}, \mathrm{P}_{4 C C}, \mathrm{P}_{5 \mathrm{CC}}$, and $\mathrm{P}_{6 \mathrm{CC}}$.

Figura 13. Esfuerzos térmicos alcanzados en la placa de INCONEL 625 LCF en los procesos de calentamiento y enfriamiento. Para condiciones normales de operación (OC) los puntos seleccionados son: $P_{10 C}, P_{20 C}, P_{30 C}, P_{40 C}$ y $P_{50 c}$. Para condiciones críticas (CC) los puntos seleccionados son: $P_{1 C C}, P_{2 C C}, P_{3 C C}, P_{4 C C}, P_{5 C C}$ y $P_{6 C C}$.

required to achieve fatigue failure, $A$ is the proportionality coefficient, and $B$ is the exponent of the fatigue stress, which is obtained from Equation (10). For this case, we estimated the following value for $B$ :

$$
B=-0.04132
$$

A is obtained from Equation (10) with the following condition: $N=1000$.

$$
A=\frac{S_{1000}}{\left(10^{3}\right)^{B}}
$$

where $S_{1000}$ is the fatigue strength at $10^{3}$ cycles.

The stress range is defined by the following equation:

$$
S_{r}=S_{\max }-S_{\min }
$$

where $S_{\max }$ is the maximum thermal tensile stress during the heating process $\left(S_{\max }\right.$ zone $)$, and $S_{\min }$ is the maximum thermal compressive stress during the cooling process $\left(S_{\min }\right.$ zone). These points were selected from Section 3 (Fig. 13).

To estimate the first cycle on the estimated fatigue curve, we need the following condition:

$$
S_{1}=S u
$$

where $S_{u}$ is the tensile strength.

The fatigue stress at $10^{3}$ cycles is estimated by an empirical correlation ${ }^{[20]}$ :

$$
S_{1000}=0.9 S u
$$

For the INCONEL 625LCF ${ }^{\circledR}$ mechanical properties described above, $A=1070.415 \mathrm{MPa}$. Using the proportionality coefficient $A$ and the exponent of 
fatigue stress $B$, it is possible to estimate the slope for the HCF region on the fatigue curve for both normal and critical operational conditions. Figures 14 and 15 present the estimated fatigue curves $\left(\log \left(S_{f}\right)-\log \right.$ $\left(N_{f}\right)$ ) for the INCONEL 625LCF ${ }^{\circledR}$. These curves show that the plate can withstand a wide range of stresses during thermal fatigue cycling at normal and critical operational conditions, respectively.

For the first case (OC), the stress rank value is approximately $130 \mathrm{MPa}\left(\mathrm{P}_{10 \mathrm{C}}\right)$; therefore, there is no intersection with the fatigue curve, whereas for an approximate value of $313 \mathrm{MPa}\left(\mathrm{P}_{2 \mathrm{OC}}\right), 10^{13}$ cycles of operation are achieved. For values near $360 \mathrm{MPa}$ $\left(\mathrm{P}_{5 \mathrm{OC}}\right)$ and $366 \mathrm{MPa}\left(\mathrm{P}_{30 \mathrm{CC}}\right)$, the plate withstands $10^{11}-10^{12}$ cycles. For the last value of approximately $447 \mathrm{MPa}\left(\mathrm{P}_{4 \mathrm{OC}}\right.$ and maximum cycle temperature nearly $759^{\circ} \mathrm{C}$ ), the number of cycles can exceed $10^{9}$ before the material fails due to thermal fatigue.

For the second case (CC) (values near $424 \mathrm{MPa}$ $\left(\mathrm{P}_{1 \mathrm{CC}}\right), 480 \mathrm{MPa}\left(\mathrm{P}_{6 \mathrm{CC}}\right)$ and $\left.495 \mathrm{MPa}\left(\mathrm{P}_{5 \mathrm{CC}}\right)\right)$, operating cycles reach $10^{8}-10^{10}$, which is within the $\mathrm{HCF}$ region. For stress values of $520 \mathrm{MPa}\left(\mathrm{P}_{3 \mathrm{CC}}\right)$ and $560 \mathrm{MPa}\left(\mathrm{P}_{4 \mathrm{CC}}\right)$, the number of cycles that the plate withstands is between $10^{6}$ and $10^{8}$ ( $\mathrm{HCF}$ region). For a value of $650 \mathrm{MPa}\left(\mathrm{P}_{2 \mathrm{CC}}\right)$ (maximum cycle temperature of $908^{\circ} \mathrm{C}$ ), the number of cycles can exceed $10^{5}$ before the material fails due to thermal fatigue.

\section{CONCLUSIONS}

- This work demonstrates the performance of accelerated aging in solar absorber materials that have been analyzed in the DISTAL-I parabolic dish located at the PSA. The DISTAL-I parabolic dish has been adapted to perform thermal cycles on materials being exposed to various levels of concentrated solar radiation. With this system, we can perform 1000 thermal cycles in 8 operational hours. Based on the results obtained for maximum thermal stress under normal and operational material conditions $\left(500 \mathrm{~kW} / \mathrm{m}^{2}, 650^{\circ} \mathrm{C}\right.$ and $800 \mathrm{~kW} / \mathrm{m}^{2}$, $908^{\circ} \mathrm{C}$ maximum temperature, respectively), we can assume that the plate will function in the $\mathrm{HCF}$ region. For metal alloys, the HCF region is defined for the range of $10^{3}-10^{8}$ cycles before any component fails by thermal fatigue.

- The second case (OC) shows that the plate will also perform in the HCF region. This has been well observed for the maximum value of $650 \mathrm{MPa}$. Critical conditions may occur while the mirror focuses sunlight on the receiver.

- For temperatures above $800^{\circ} \mathrm{C}$, thermal stresses may approach the ultimate strength and cause the material to fail due to fatigue at a low number of cycles.

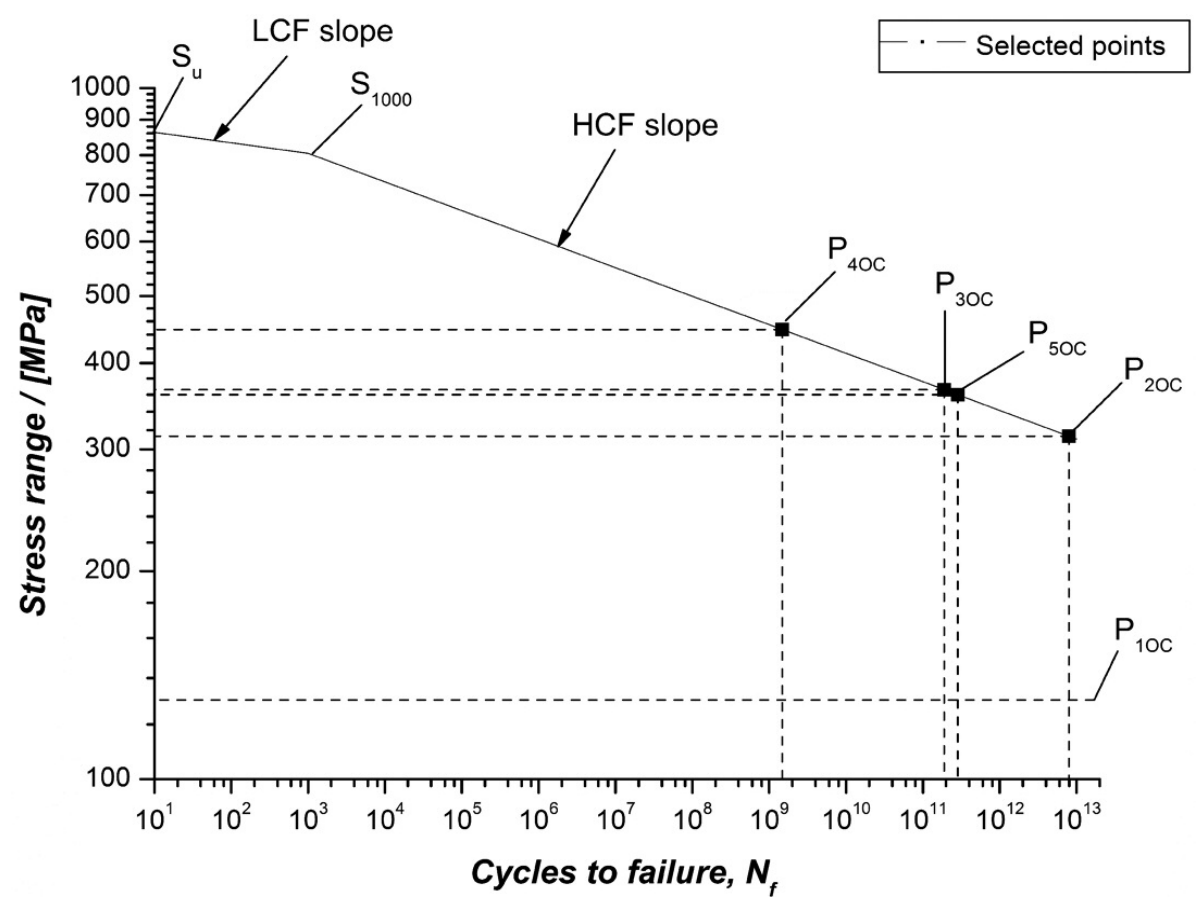

Figure 14. Estimate of S-N fatigue curve for the INCONEL 625LCF at the normal operational condition.

Figura 14. Estimación de la curva de fatiga S-N, para el INCONEL 625LCF, condición de operación normal. 


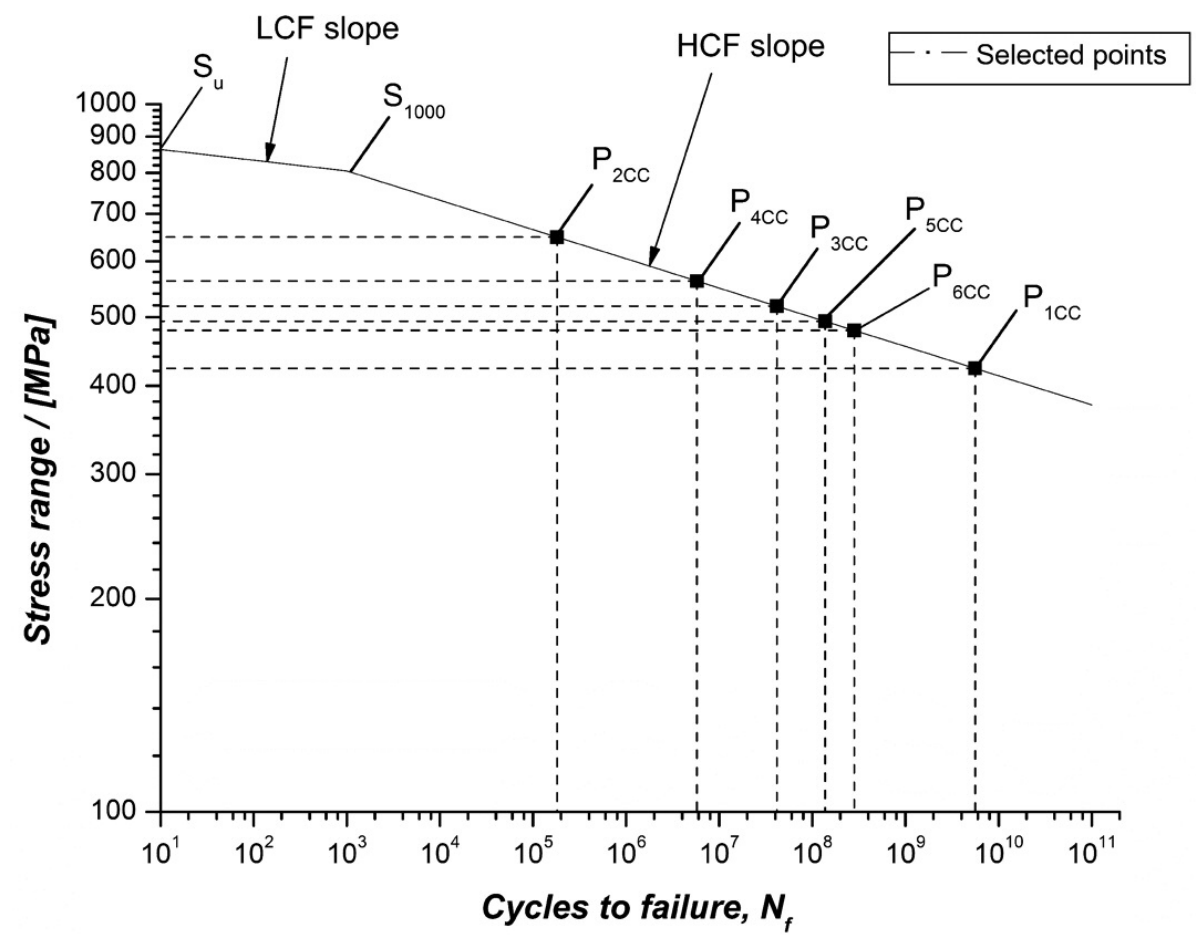

Figure 15. Estimate of S-N fatigue curve for the INCONEL 625LCF at the critical operational condition.

Figura 15. Estimación de la curva de fatiga S-N, para el INCONEL $625 L C F$, condición de operación crítica.

\section{Acknowledgements}

The authors wish to thank to the Spanish Ministerio de Industria, Turismo y Comercio for supporting the AVANSOL project (PROFIT, CIT-120000-200549). A. Rojas would also like to thank the PROFIP program of the Universidad Nacional Autónoma de México, L. Yolanda Flores-Salgado for her assistance in writing the simulation code and processing the artwork, and Zenaida Peralta-Inga, who provided valuable comments on the manuscript.

\section{REFERENCES}

[1] R. Osuna, V. Fernández-Quero, M. Sánchez, Proc. 14th Biennial CSP SolarPACES Symposium, Las Vegas, EE.UU., 2008.

[2] R.Z. Litwin, Receiver System: Lessons Learned from Solar Two. Sandia National Laboratories, SAND2002-0084, Albuquerque, NM, EE.UU., 2002, pp. 30-36.

[3] J.M. Lata, M. Rodriguez, and M. Alvarez de Lara, Proc. 13th International Symposium on
Concentrated Solar Power and Chemical Energy Technologies. Sevilla, Spain, 2006.

[4] A. Usman, and K. Nusair, Eng. Fail. Anal. 15 (2008) 118-128.

[5] C. Clifford, Hand book of case histories in failure analysis ASM International, EE.UU., 1996, pp. 214-216.

[6] D.N. French, Metallurgical failures in fossil fired boilers, Ed. Wiley-Interscience Publication, New York, EE.UU., 1983, pp. 98-110.

[7] D.R.H. Jones, Eng. Fail. Anal. 11 (2004) 873-893.

[8] A. Ul-Hamid, H.M. Tawancy, M. ARI and N.M. Abbas, Eng. Fail. Anal. 13 (2006) 1005-1021.

[9] P. Heller, W. Reinalter, and D. Martínez, Proc. $10^{\text {th }}$ International Stirling Engine Conference, Osnabruck, Germany 2001.

[10] W. Reinalter, S. Ulmer, P. Heller, T. Rauch J-M. Gineste, A. Ferriere and F. Nepveu, Proc. 13th International Symposium on Concentrated Solar Power and Chemical Energy Technologies. Sevilla, Spain, 2006.

[11] T. Wendelin, Proc. of the ISEC, ASME, Kohala Coast, Hawaii, New York, EE.UU., 2003, pp. 253-260. 
[12] C.R. Steele, C.D. Balch, G.J. Jorgensen, T. Wendelin, and A. Lewandowski, Membrane Dish Analysis: A Summary of Structural and Optical Analysis Capabilities, National Renewable Energy Laboratory, NREL/TP-253-3432, Golden, CO, EE.UU., 1991, pp. 1.3-9.

[13] A.C. Ratzel, and B.D. Boughton, CIRCE.001: A Computer Code for Analysis of Point-Focus Concentrators with Flat Targets. Sandia National Laboratories, SAND86-1866, Albuquerque, NM, EE.UU., 1987, pp. 1-3.

[14] H. Albaugh, R. Venuti, and C. Hoggatt, Int. J. Fatig. 2 (1980) 85-89.

[15] G. Dini, Eng. Fail. Anal. 15 (2008) 445-457.

[16] F.P. Incropera and D.P. DeWitt, Fundamentos de Transferencia de Calor, Ed. Prentice Hall México, 1999, pp. 348-395.

[17] INCONEL ${ }^{\circledR}$ alloy 625LCF® [On line] Technical Bulletin SMC-020. Special Metals Corporation. 2006. [Access date: November 2008]. Available: http://www.specialmetals. com/documents/Inconel\%20alloy\%20625LCF.pdf.

[18] R. Avilés, Análisis de Fatiga en Máquinas, Ed. Thomson, Madrid, España, 2005, pp. 209-210.

[19] R.I. Stephens, A. Fatemi, R.R. Stephens and H-O. Fuchs, 2001. Metal Fatigue in Engineering, Ed, John Wiley \& Sons, Inc. New York, EE.UU., 2001, pp. 83-86.

[20] Y. Lee, J. Pan, R.B. Hathaway and M.E. Barkey, Fatigue Testing and Analysis, Ed. Elsevier, New York, EE.UU. 2005, pp. 126-131. 